\title{
The Calculated Binding Energy of Peptide-mimic Inhibitors with Some Mutated HCV NS3 Protease
}

\author{
Noha A. Saleh \\ Biophysics Department, Faculty of Science, Cairo University, Giza 12613, Egypt
}

\begin{abstract}
$\mathbf{H}_{\circ}$ EPATITIS C virus is considered one of the worldwide viruses with very large percentage of infection in population. It is as an epidemic disease in Egypt. The introduced compounds ( $\mathrm{a}$ and $\mathrm{b}$ ) in this study were previously investigated and gave good binding affinity and good inhibition activity with wild-type HCV NS3 protease. In the present work, calculated molecular docking and binding energy calculations are performed to predict the inhibition activity of suggested compounds against some mutated HCV NS3 proteases. Compound a has hexa-peptide with $\alpha$-ketoacids instead of the thiol group $(\mathrm{SH})$ of cysteine residues attached to monomer cellulose at position 6 and compound $b$ has hexa-peptide with $\alpha$-ketoacids instead of the thiol group $(\mathrm{SH})$ of cysteine residues attached to dimer cellulose at position 6 . Based on the calculated binding energy and number of hydrogen bonds in docking interaction between the compounds and mutated NS3 protease, the inhibition activity of compounds $\mathbf{a}$ and $\mathbf{b}$ with NS3 protease mutations is more than that with wild-type NS3 protease. Especially withD168V NS3 protease mutation. The mutation in virus enzymes is one of the major obstacles in hepatitis $\mathrm{C}$ virus treatment.
\end{abstract}

Keywords: Binding energy, Docking, HCV, Molecular modelling, NS3 protease inhibitor, NS3 protease mutation.

\section{Introduction}

The behavior (physically, chemically and biologically) of any molecular system can be predicted using molecular modelling. Molecular modelling is based on theoretical methods and main physics principals (classical and quantum laws) for simulating and understanding the physical, chemical and biological properties of any molecules or molecular systems. Computer-based methods and modelling are utilized in molecular modelling to calculate many physical parameters like optimization energy and geometry, structure and energy of transition state, atomic charges, molecular and atomic orbitals, thermodynamic and magnetic properties, IR, UV, Raman \&NMR spectra, electron \& proton affinity, multipole moment, ionization potential and so on. It also provides information on chemical properties such as chemical reactivity and reaction pathway. This is in addition to the calculation of biological properties by predicting the structure-activity relationships and rational drug design [1-6]. Therefore, molecular modelling calculations are very essential tosave efforts, time and money andhelp in designing new drugs against many viruses and bacteria.
The most important part in the development of protein-based drugs is a drug design. The process of drug design is the discovery of new compounds and development of current compoundsor drugs to increase the specific activity on an organism. The design and modification of drug is expensive and time-consuming and is considered as interdisciplinary process. [2,7,8]. Therefore, molecular modelling technology and facilities are useful and help in accelerating and decreasing the costs of drug developmentdown to $50 \%$. They also help in the design, selection, and lead identification of newdrugs and ligands. Computer-Aided Drug Design (CADD) is used to study the structure of drug and its biological activity [9-11].

The two major categories in CADD are structure-based drug design and ligand-based drug design. In structure-based drug design, docking simulation is the most essential process. Molecular docking is used to predict the ligand's conformations and orientation inside a protein or enzyme through a protein-ligand or proteinprotein complex simulation [8-15]. The main calculation in ligand-based drug design is Quantitative Structure-Activity Relationship (QSAR) which is calculated by statistical and

nsaleh $@$ sci.cu.edu.eg

DOI :10.21608/ejphysics.2018.5269.1009

C2019 National Information and Documentation Center (NIDOC) 
mathematical equations. The QSAR descriptors give the relationship between a biological property and the structure within a family of compounds [10, 11, 16, and 17].

The development of inhibitors and antiviral drugs such as anti-hepatitis $\mathrm{C}$ virus is one of the serious applications [18-27]. One of the most common viruses in the world is hepatitis $\mathrm{C}$ virus (HCV). $\mathrm{HCV}$ is a third type of hepatitis virus discovered after hepatitis A and B in 1970 . Its genome was identified in 1989 [28]. It is responsible for liver disease reported worldwide ( $\sim 3 \%$ of the world's population, $150-200$ million people) especially in Asia and North of Africa $[29,30]$. Over $85 \%$ of HCV infected people will develop chronic hepatitis which may progress to liver cirrhosis and Hepatocellular Carcinoma $[31,32]$. HCV is one member of the Flaviviridae family with a single positive-strand RNA. $\mathrm{HCV}$ genome encodes to 10 polypeptides, each with a distinct and important function for virus replication. Four of these functional proteins are called structural proteins (C, E1, E2 and p7) and six of them are named non-structural proteins (NS2, NS3, NS4A, NS4B, NS5A, and NS5B) [33-39].

Egypt has the highest HCV infection percentage worldwide (with almost $20 \%$ of the population being infected). The most common sub-genotype in Egypt is 4a [40-42]. As yet, there is no vaccine to prevent $\mathrm{HCV}$ infection. The current therapy causes many side effects as well as it is expensive andeffective in only $50-80 \%$ of patients. This therapy is a combination of Interferon alpha (IFN) with the ribavirin [43-46]. Nevertheless, recently some anti-HCV inhibitors targeting HCV NS3 protease, NS5B or NS5Ahave been approved [46-48]. Still there is a need to investigate more effective $\mathrm{HCV}$ inhibitors.

Recently, structure-based drug design (molecular docking) and ligand-based drug design (QSAR) are performed to study the inhibition activity of novel compounds as $\mathrm{HCV}$ NS3 protease inhibitors [24,49]. These inhibitors consist of monomer or dimer cellulose and hexapeptide sequences. The hexa-peptide sequences is the NS5A/NS5B junction for the Egyptian genotype 4 (Glu-Asp-Val-Val-Cys-Cys) [41,42]. These hexapeptide sequences are modified by replacing the $\alpha$ amino acids sequences with $\beta$-amino acids [50], mix of $\alpha$ - and $\beta$-amino acids [50], $\alpha$-ketoacids [51-53] instead of the thiol group $(\mathrm{SH})$ of cysteine residues or phenyl acyl sulfonamide $[54,55]$ instead of the C-terminal carboxylic acid $[24,49]$. According to these studies, the two compounds a and b (Fig. 1) have good inhibition activity against wild-type $\mathrm{HCV}$ NS3 protease. Compound a hashexa-peptide with $\alpha$-ketoacids instead of the thiol group ( $\mathrm{SH}$ ) of cysteine residues attached to monomer cellulose at position 6 and compound $\mathbf{b}$ has hexa-peptide with $\alpha$-ketoacids instead of the thiol group ( $\mathrm{SH}$ ) of cysteine residues attached to dimer cellulose at position $6[24,49]$.

In this study, molecular docking and binding energy calculations are performed to evaluate the inhibition activity of compounds $a$ and $b$ against some HCV NS3 proteasemutations. The selected NS3 protease mutations are A156S, A156T, D168A, D168G, D168I, D168V, F43S, V36G, V36L and V36M [56-57].

\section{Computational details}

The HCV NS3 protease with PDB code: 3LOX from the Protein Data Bank (PDB) [58] is used to prepare the NS3 protease mutations using SCIGRESS 3.0 software [59]. The selected NS3 protease mutations are A156S, A156T, D168A, D168G, D168I, D168V, F43S, V36G, V36L and V36M. To optimize the mutated NS3 protease, the MM3 method is performed after adding hydrogen atoms [60]. Molecular docking calculations between the compounds and the ten mutated HCV NS3 protease are carried out using SCIGRESS 3.0 software. In docking calculations, the Gly137 and the catalytic conserved triad residues of the active site of NS3 protease (His57, Asp81 and Ser139) are selected as agroup. PMF04 and FASTDOCK [61] scoring functions are used in order to find the best score for binding affinity of the studied compounds.Genetic algorithm is utilizing in these scoring functions. During the docking calculation, the selected active site residues of mutated NS3 protease and the studied compounds are flexible. Finally, the binding free energy is calculated for the best scores of the docking systems at MM3 level. The binding energy is calculated according to the following equation $[24,49]$ :

\section{$\Delta \mathrm{G}_{\text {Binding }}=\mathrm{G}_{\text {Complex }}-\left(\mathrm{G}_{\text {Ligand }}+\mathrm{G}_{\text {Receptor }}\right)$}

\section{Results and Discussion}

Previous studies investigated the inhibition activity of novel suggested compounds against $\mathrm{HCV}$ NS3 protease and showed that the compounds which consist of (monomer or 
dimer) cellulose and hexapeptide sequences (Glu-Asp-Val-Val-Cys-Cys) at position 6 with $\alpha$-ketoacids instead of the thiol group (SH) of cysteine residues (Fig. 1) hadthe lowest binding energy and highest binding affinity with wildtype NS3 protease [24, 49]. In this study the inhibition activity of these compounds against some mutated NS3 protease (A156S, A156T, D168A, D168G, D168I, D168V, F43S, V36G, $\mathrm{V} 36 \mathrm{~L}$ and $\mathrm{V} 36 \mathrm{M}$ ) is investigated and also the binding energy of docking interaction systems is calculated. The studied compounds involved in this study are compound a consisting of monomer cellulose and hexapeptide sequences (Glu-Asp-Val-Val-Cys-Cys) at position 6 with $\alpha$-ketoacids instead of the thiol group ( $\mathrm{SH}$ ) of cysteine residues and compound b consisting of dimer cellulose and hexapeptide sequences (Glu-Asp-Val-Val-Cys-Cys) at position 6 with $\alpha$-ketoacids instead of the thiol group ( $\mathrm{SH}$ ) of cysteine residues (Fig. 1). a)

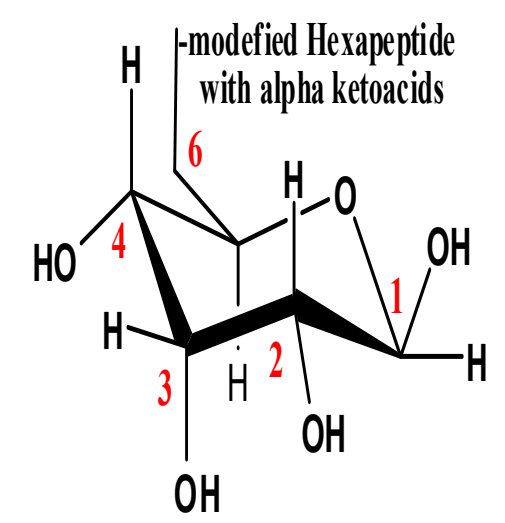

b)

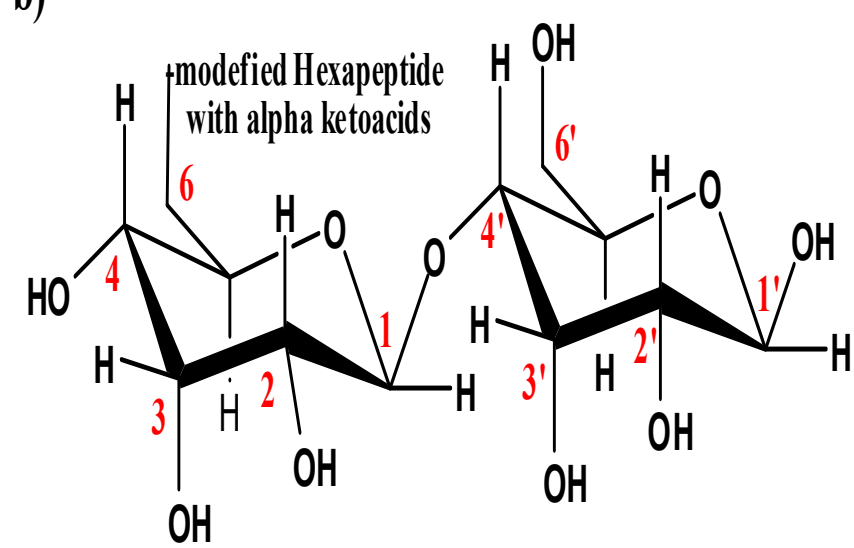

Fig. 1. The general structure of the suggested compounds. a) monomer cellulose $+\alpha$-ketoacids instead of the thiol group (SH) of cysteine residues. b) dimer cellulose $+\alpha$-ketoacids instead of the thiol group (SH) of cysteine residues.

The binding energy, number of hydrogen bonds (H-bonds) and the amino acids involved in the H-bonds are calculated for docking interaction between the suggested compoundsand mutated HCV NS3 protease. These calculated parameters are listed in Table 1. Based on the docking calculations, the calculated binding energy of interaction between the suggested compounds and mutated NS3 proteasesis compared with the calculated binding energy of interaction between these compounds and wild-type NS3 protease. As shown in Table 1, the binding energy for compound a with wild-type NS3 protease is equal to $-95.17 \mathrm{kcal} / \mathrm{mol}$, while, with studied NS3 protease mutations, it varies from $-122.53 \mathrm{kcal} /$ mol to $-77.29 \mathrm{kcal} / \mathrm{mol}$. The binding affinity of compound a against the selected NS3 protease mutationsis less than that against wild-type NS3 protease except mutations D168A, D168G, F43S, V36G and V36M. On the other hand, compound bhas a value of $-97.77 \mathrm{kcal} / \mathrm{mol}$ as binding energy with the wild-type NS3 protease. The calculated binding energy of interaction between compound $\mathrm{b}$ and studied mutated NS3 proteases varies from $-128.1 \mathrm{kcal} / \mathrm{mol}$ to $-65.71 \mathrm{kcal} / \mathrm{mol}$. Compound bshows better inhibition activity against mutated NS3 protease than compound a.Compound bforms lower binding energy with mutated NS3 proteases than wild-type NS3 protease except for two mutations (D168A and F43S) which have binding energy larger than that with wildtype NS3 protease. For both compounds a and b, the lowest binding energy is with the mutation D168V.

Figure 2 presents the mode of docking interaction with D168VNS3 protease mutation. Table 1 and Fig. 2 show the involved amino acids and $\mathrm{H}$-bonds in these interactions. Compound a forms nine $\mathrm{H}$-bonds with mutated NS3 protease D168V, while compound $\mathrm{b}$ forms ten H-bonds. For compound a, one H-bond is formed with each of Gln41, His57, Dsp81, Thr40, Arg62, Lys136 and Val78 and two H-bonds are formed only with Arg155. For compound b, one H-bond is formed with each ofHis57 and Dsp81, Thr40, and Val78 and two H-bonds are formed with each 
of Arg62, Lys136, Arg155 and Gln41. The number of $\mathrm{H}$-bonds and the involved amino acids in studied docking interactions are shown in Table 1. All docking systems with NS3 protease mutations form more H-bonds than that with wild-type NS3 protease.As shown in Table 1, also the num- ber of involved amino acids in interaction system for mutated NS3 proteases is more than that for wild-type NS3 protease. This indicates that the inhibition activity of compounds a and b with NS3 protease mutations is more than that with wildtype NS3 protease.

TABLE 1. Calculated binding energy of interaction between the suggested inhibitors and NS3 protease at MM3 method. The number of $\mathrm{H}$-bonds and the amino acids involved in $\mathrm{H}$-bond formation between the ligand and NS3 protease are also shown.

\begin{tabular}{|c|c|c|c|c|c|c|}
\hline \multirow[b]{2}{*}{$\begin{array}{c}\text { NS3 } \\
\text { protease }\end{array}$} & \multicolumn{3}{|c|}{ Compound a } & \multicolumn{3}{|c|}{ Compound b } \\
\hline & $\begin{array}{c}\text { Binding } \\
\text { energy } \\
\text { (kcal/mol) }\end{array}$ & H-bonds & $\begin{array}{c}\text { Involved amino } \\
\text { acids }\end{array}$ & $\begin{array}{c}\text { Binding } \\
\text { energy } \\
\text { (kcal/mol) }\end{array}$ & H-bonds & $\begin{array}{c}\text { Involved amino } \\
\text { acids }\end{array}$ \\
\hline Wild-type* & -95.17 & 3 & D81, R155. & -97.77 & 3 & H57, R123, R155. \\
\hline A156S & -115.19 & 10 & $\begin{array}{l}\text { T40, T56, H57, } \\
\text { R62, D81, K136, } \\
\text { R155, S156, A157, } \\
\text { D168. }\end{array}$ & -110.36 & 4 & K20, S56, H57, D168. \\
\hline A156T & -112.75 & 8 & $\begin{array}{c}\text { T40, Q41, H57, } \\
\text { K136, A157. }\end{array}$ & -121.04 & 7 & $\begin{array}{l}\text { Q41, R123, K136, } \\
\text { R155,T156, D168. }\end{array}$ \\
\hline D168A & -92.86 & 6 & $\begin{array}{c}\text { Q41, T56, H57, } \\
\text { K136, S139. }\end{array}$ & -65.71 & 6 & $\begin{array}{l}\text { V78, D81, S122, } \\
\text { R123, R155. }\end{array}$ \\
\hline D168G & -91.33 & 7 & $\begin{array}{l}\text { Q41, H57, D81, } \\
\text { R155, A157. }\end{array}$ & -115.16 & 7 & $\begin{array}{l}\text { Q41, D79, R123, } \\
\text { R155. }\end{array}$ \\
\hline D168I & -99.48 & 7 & $\begin{array}{l}\text { T40, Q41, H57, } \\
\text { R62, D81, K136, } \\
\text { A157. }\end{array}$ & -107.03 & 7 & $\begin{array}{c}\text { T40, Q41, H57, A59, } \\
\text { R62. }\end{array}$ \\
\hline D168V & -122.53 & 9 & $\begin{array}{l}\text { T40, Q41, H57, } \\
\text { R62, V78, D81, } \\
\text { K136, R155. }\end{array}$ & -128.10 & 10 & $\begin{array}{c}\text { Q41, H57, } \\
\text { R62,D81,K136, R155. }\end{array}$ \\
\hline F43S & -86.09 & 7 & $\begin{array}{l}\text { H57, D81, K136, } \\
\text { S139, A157. }\end{array}$ & -95.15 & 5 & $\begin{array}{l}\text { Q41, H57, R62, } \\
\text { R155,D168. }\end{array}$ \\
\hline V36G & -94.68 & 7 & $\begin{array}{l}\text { T40, Q41, R62, } \\
\text { R123, A157. }\end{array}$ & -113.48 & 8 & $\begin{array}{l}\text { S22, Q41, H57, D81, } \\
\text { R123, K136, R155. }\end{array}$ \\
\hline V36L & -105.53 & 10 & $\begin{array}{l}\text { T40, Y56, H57, } \\
\text { G58, R62, R123, } \\
\text { K136. }\end{array}$ & -113.62 & 4 & Y56, H57, V78, R155. \\
\hline V36M & -77.29 & 8 & $\begin{array}{l}\text { T40, Q41, H57, } \\
\text { A59 R62, D81, } \\
\text { K136. }\end{array}$ & -117.08 & 10 & $\begin{array}{l}\mathrm{K} 20, \mathrm{H} 57, \mathrm{~K} 136 \\
\quad \mathrm{R} 155, \mathrm{D} 168\end{array}$ \\
\hline
\end{tabular}

* Adapted from [49] 


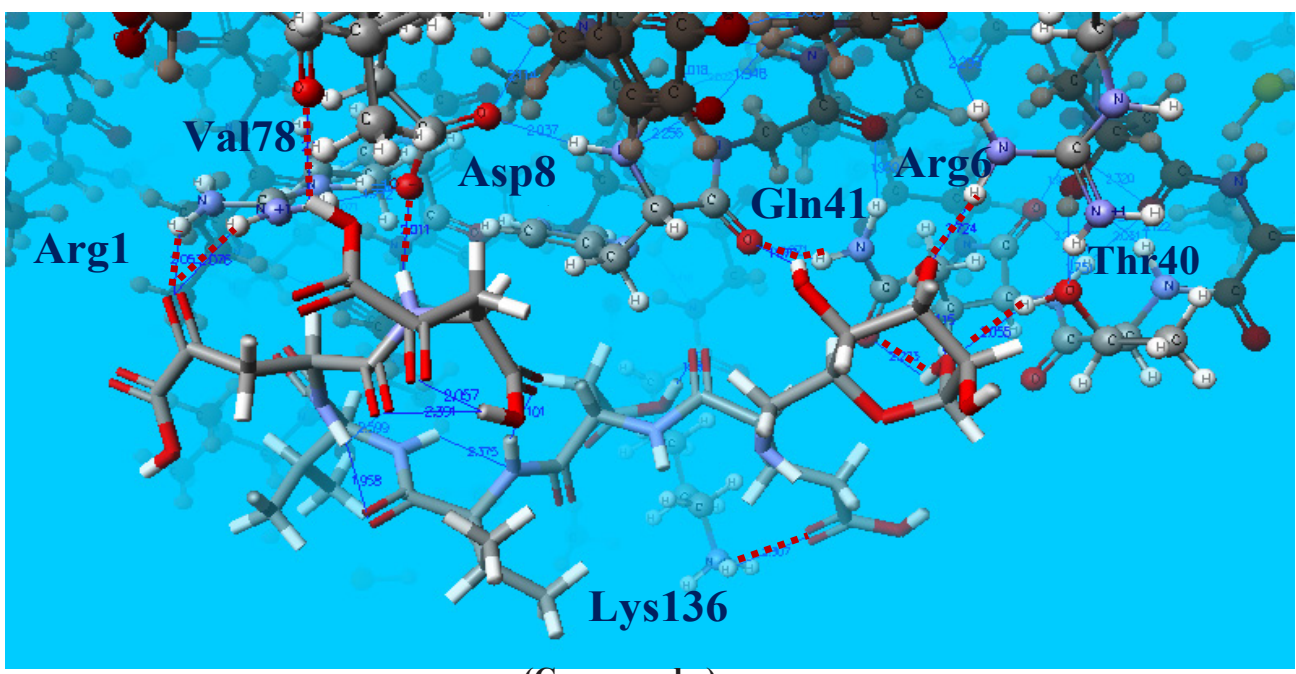

(Compound a)

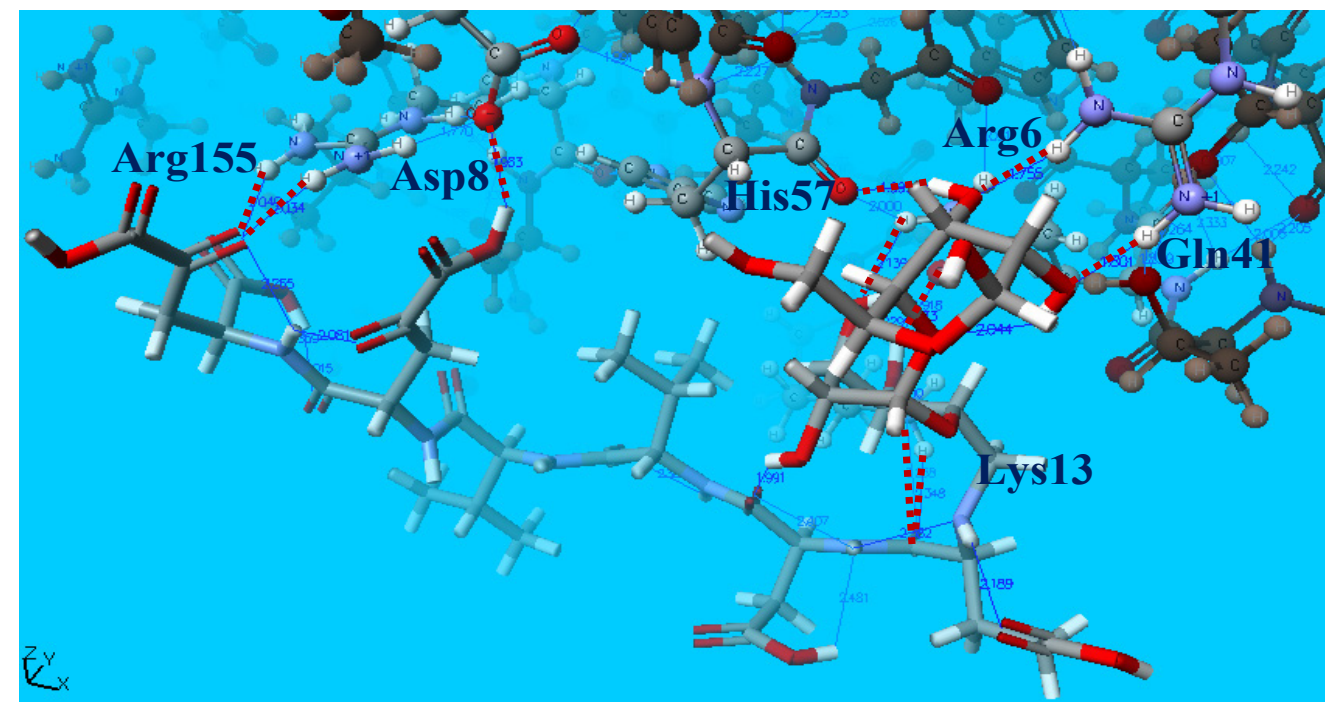

(Compound b)

Fig. 2. The docking systems and mode of interaction between the ligands and mutated HCV-NS3 protease (D168V). The cylindrical molecules represent the studied compounds and the ball \& cylinder molecules represent the amino acid residues of protein (The cyan, white, red, blue and yellow colors represent the carbon, hydrogen, oxygen, nitrogen and sulfur atoms, respectively). The red dashed lines represent the hydrogen bonds between the ligands and amino acid residues of protein.

\section{Conclusion}

The modification of hexapeptide sequences (Glu- Asp- Val-Val-Cys- Cys) at position 6 with $\alpha$-ketoacids instead of the thiol group ( $\mathrm{SH}$ ) of cysteine residues increases the binding affinity with mutated NS3 proteases. This indicates that the studied compounds may behave asgood inhibitors against HCV NS3 protease mutations (especially with D168V mutated NS3 protease) which is one of the major obstacles in hepatitis $\mathrm{C}$ virus treatment.Hopefully, compounds a and b will be further tested in future in a specially designed in vitro study against HCV protease. Conflict of interest: The author declares that there are no conflicts of interest related to this work.

\section{Acknowledgment}

The author would like to thank Prof. Dr. Wael M. Elshemey, Biophysics Department, Faculty of Science, Cairo University for the valuable comments that greatly improved of the manuscript. 


\section{References}

1. Leach, A.R., Molecular Modelling Principle and Applications,"Addison Wesley Longman Limited, Edinburgh Gate, Harlow, Essex CM20 2JE, England, p. 640 (1996).

2. Cohen, N.C., Guidebook on Molecular Modeling in Drug Design,"Academic Press, Inc. (1996).

3. Cramer, C.J., Essentials of Computational Chemistry Theories and Models"Second edition, John Wiley \& Sons Ltd, The Atrium, Southern Gate, Chichester, West Sussex PO19 8SQ, England, p1 (2004).

4. Hinchliffe, A., Molecular Modelling for Beginners," Second edition, JohnWiley \& Sons Ltd, p37 (2008).

5. Jensen, J.H., Molecular Modeling Basics"Taylor and Francis Group, LLC, p.103 (2010).

6. Lewars, E.G., Computational Chemistry Introduction to the Theory and Applications of Molecular and Quantum Mechanics"Third edition, Springer International Publishing Switzerland, p1 (2016).

7. Lundblad, R.L., Encyclopedia of Cell Biology, 1, 135 (2016)

8. MerzJr. K.M., Ringe, D. and Reynolds, C.H., Drug Design: Structure- And Ligand-Based Approaches" Cambridge University Press (2010)

9. Taft, C.A., Silva V.B., and Silva, C.H.T.P., J. Pharm. Sci. 97, 1089 (2008).

10. Aguayo-Ortiz, R., and Gortari, E.F., Overview of Computer-Aided Drug Design for Epigenetic Targets"Chapter 2, Elsevier Inc. (2016).

11. Huang, H., Yu, H.W., Chen, C., Hsu, C., Chen, H., Lee, K., Tsai, F.and Chen, C.Y., J. Taiwan. Inst. Chem. E., 41, 623 (2010).

12. Warren, G.L., Do, T.D., Kelley, B.P., Nicholls, A. and Warren, S.D., Drug Discov. Today, 17, (2324), 1270 (2012).

13. Zheng, M., Liu, X., Xu, Y., Li, H., Luo, C. and Jiang, H., Trends Pharmacol. Sci., 34, 549 (2013).

14. Pei, J., Yin, N., Ma, X. and Lai, L., J. Am. Chem. Soc., 136, 11556 (2014).

15. Chen, Y., Beware of docking!, Trends Pharmacol. Sci., 36, 78 (2015).

16. Ibrahim, M., Saleh, N.A. and Elshemey, W.M.,
Editor, Khan, M.T.H., Recent Trends on QSAR in the Pharmaceutical Perceptions," Bentham Science Publisher, Netherlands, p. 360 (2012).

17. Davis, A.M., Encyclopedia Comprehensive Medicinal Chemistry III, 379, (2017).

18. Ibrahim M., Saleh, N.A., Elshemey, W.M. and Elsayed, A.A., J. Comput. Theor. Nanosci. 10 (4), 785 (2013).

19. Weidlich, I.E., Filippov, I.V., Brown, J., KaushikBasu, N., Krishnan, R., Nicklaus, M.C. and Thorpe, I.F., Bioorgan. Med. Chem., 21, 3127 (2013).

20. Saleh, N.A., Elfiky, A.A., Ezat, A.A., Elshemey, W.M. and Ibrahim, M., J. Comput. Theor. Nanosci. 11(2), 544 (2014).

21. Mostafa, H.I.A., El-bialy, N.S., Ezat, A.A., Saleh, N.A., and Ibrahim, M., Curr. Comput.-Aid Drug, 10 (1), 28 (2014).

22. Saleh, N.A., Ezat, A.A., Elfiky, A.A., Elshemey, W.M. and Ibrahim, M., J. Comput. Theor. Nanosci. 12, 371 (2015).

23. Saleh, N.A., Elhaes, H. and Ibrahim, M., "Design and Development of Some Viral Protease Inhibitors by QSAR and Molecular Modeling Studies" a book chapter in Viral Proteases and Their Inhibitors" Elsevier, DOI:10.1016/B978-012-809712-0.00002-2., p 25, (2017).

24. Saleh, N.A. and Elshemey, W.M., Life Science, 187, 58 (2017).

25. Balasubramanian, K. and Patil, V.M., Comput. Biol. Chem., 73, 147 (2018).

26. Elfiky, A.A. and Ismail, A.M., Future. Virol. 12 (7), 339 (2017).

27. Elfiky, A.A., Mahdy, S.M. and Elshemey, W.M., $J$. Med. Virol. 89 (6), 1040 (2017).

28. Choo, Q.L., Kuo, G., Weiner, A.J., Overby, L.R., Bradley, D.W. and Houghton, M., Science, 244, 359 (1989).

29. Patel, P.D., Patel, M.R., Basu, N.K. and Talele, T.T., J. Chem. Inf. Model. 48, 42 (2008).

30. MohdHanafiah, K., Groeger, J., Flaxman, A.D. and Wiersma, S.T., Hepatology, 57, 1333 (2013).

31. Hirashima, S., Suzuki, T., Ishida, T., Noji, S., Yata, S., Ando, I., Kamatsu, M., Ikeda, S. and Hashimoto, H., J. Med. Chem. 49, 4721 (2006). 
32. Ghany, M.G., Strader, D.B., Thomas, D.L., Seeff, L.B., Hepatology, 49, 1335 (2009).

33. Francesco, R.D., Hepatology, 31, 47 (1999).

34. McLauchlan, J., J. Viral Hepat., 7, 2 (2000).

35. Moradpour, D., Penin, F. and Rice, C.M., Nat. Rev. Microbiol. 5, 453 (2007).

36. Ashfaq, U.A., Javed ,T., Rehman, S., Nawaz, Z. and Riazuddin, S., Virol. J., 8,161 (2011).

37. Moradpour, D. and Penin, F., Curr. Top. Microbiol. Immunol., 369, 113 (2013).

38. Atoom, A.M., Taylor, N.G. and Russell, R.S., Virology, 462-463, 377 (2014).

39. Rodríguez-Rodrígueza, M., Telloa, D., GómezGutiérreza, J., Peterson, D.L., Gavilanesa, F. and Yélamosa, B., BBA-Biomembranes, 1860, 728 (2018).

40. Tibbs, C.J., and Trans. R., Soc. Trop. Med. Hyg., 91, 121 (1997).

41. Timm, J., Neukamm, M., Kuntzen, T., Kim, AY., Chung, R.T., Brander, C., Lauer, G.M., Walker, B.D. and Allen, T.M., Viral Hepatitis, 14, 330 (2007).

42. Kamal, S.M. and Nasser, I.A., Hepatology, 47 (4), 1371 (2008).

43. McHutchison, J.G., Gordon, S.C., Schiff, E.R., Shiffman, M.L., Lee, W.M., Rustgi, V.K., Goodman, Z.D., Ling, M.H., Cort, S. and Albrecht, J.K., N. Engl. J. Med., 339, 1485 (1998).

44. Par, A., Telegdy, L., Dalmi, L. and Muller, E., J. Physiology-Paris, 95, 399 (2001).

45. Taylor, D.R., Shi, S.T. and Lai, M.M.C., Microbes Infect., 2, 1743 (2000).

46. Carnero, E. and Fortes, P., Virus Research, 212, 85 (2016).

47. Poordad, F. and Dieterich, D., J. Viral. Hepat., 19, 449 (2012).

48. Zhang, X., Acta Pharmaceutica Sinica B, 6 (1), 26 (2016).

49. Saleh, N.A., Physical Properties and Biological Activity of Some Novel HCV NS3 Protease
Inhibitors, Egyptian Journal of Physics, 46, pp. 29-40 (2018) .

50. Nurbo, J., Peterson, S.D., Dahl, G., Danielson, U.H., Karlen, A. and Sandstrom A., Bioorg. Med. Chem., 16, 5590 (2008).

51. Narjes, F., Brunetti, M., Colarusso, S., Gerlach, B., Koch, U., Biasiol, G., Fattori, D., De Francesco, R., Matassa, V.G. and Steinkühler, C., Biochemistry, 39 (7) 1849 (2000).

52. Colarusso, S., Gerlach, B., Koch, U., Muraglia, E., Conte, I., Stansfield, I., Matassa, V.G. and Narjes, F., Bioorg. Med. Chem. Lett. 12, 705 (2002).

53. Nizi, E., Koch, U., Ponzi, S., Matassay, V.G. and Gardelli, C., Bioorg. Med. Chem. Lett. 12, 3325 (2002).

54. Ronn, R., Sabnis, Y.A., Gossas, T., Akerblom, E., Danielson, U.H., Anders Hallberga, A. and Johansson, A., Bioorg. Med. Chem., 14, 544 (2006).

55. Johansson, A., Poliakov, A., Akerblom, E., Wiklund, K., Lindeberg, G., Winiwarter, S., Danielson, U.H., Samuelssonc, B. and Hallberga, A., Bioorg. Med. Chem., 11, 2551 (2003).

56. Ezat, A.A., El-Bialy, N.S., Mostafa, H.I.and Ibrahim, M.A., The Protein Journal., 33 (1), 32 (2014).

57. Sorbo, M.C., Cento, V., Di Maio, V.C., Howe, A.Y., Garcia, F., Perno, C.F.and Ceccherini-Silberstein, F. Hepatitis C virus drug resistance associated substitutions and their clinical relevance: Update 2018. Drug Resistance Updates. 37, 17 (2018).

58. Bennett, F., Huang, Y., Hendrata, S., Lovey, R., Bogen, S.L., Pan, W., Guo, Z., Prongay, A., Chen, K.X., Arasappan, A., Venkatraman, S., Velazquez, F., Nair, L., Sannigrahi, M., Tong, X., Pichardo, J., Cheng, K.C., Girijavallabhan, V.M., Saksena, A.K. and Njoroge, F.G., Bioorg. Med. Chem. Lett., 20, 2617 (2010).

59. Stewart, J.J.P., SCIGRESS, Version 2.9.0, Fujitsu Limited, United States, (2009).

60. Lii, J. and Allinger, N.L., J. Am. Chem. Soc., 111, 8576 (1989).

61. Muegge, I., Perspect. Drug Discov. Des., 20, 99 (2000). 
حساب طاقة الترابط لمثبطات شبيهة البييتيدات مع بعض طفرات لاتزيم

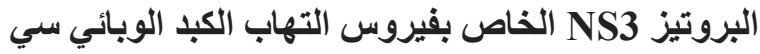

نهى صالح الحيز

قسم الفيزياء الحيوية ـ كلية العلوم - جامعة القاهرة ـ الجيزة - مصر

يعتبر فيروس الالتهاب الكبدي سي من الفيروسات العالمية ذات النسبة الكبيرة جداً من العدوى بين السكان في

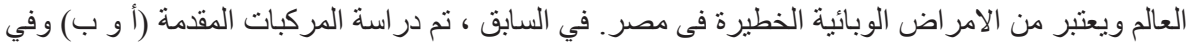

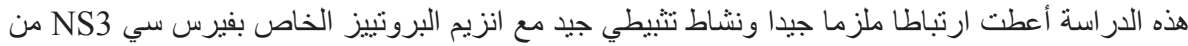

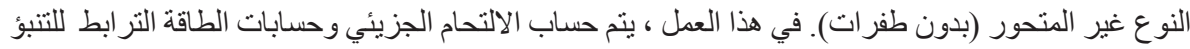

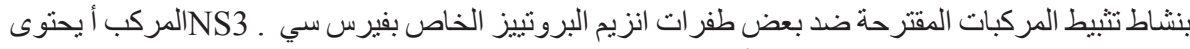

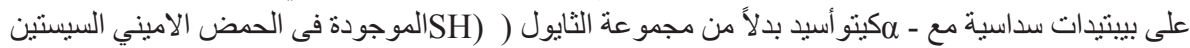

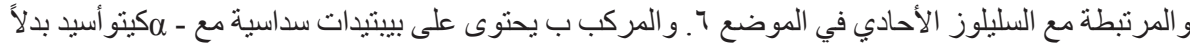

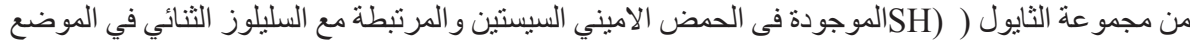

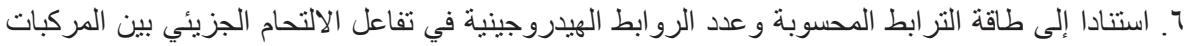

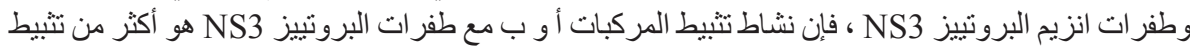

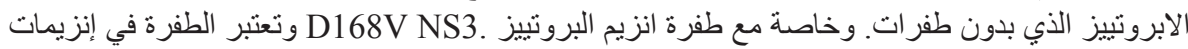
الفيروسات إحدى العقبات الرئيسية في علاج فيروس التهاب الكبد الوبائي سي. 